\title{
Photography and Tourism Potential of Denai Kuala Village
}

\author{
Agung Suharyanto ${ }^{1}$, Rehia K. Isabella Barus ${ }^{2}$, Bebby Masitho Batubara ${ }^{1}$ \\ ${ }^{1}$ Public Administration Study Program, Faculty of Social and Political Sciences, University of Medan \\ Area, Indonesia \\ ${ }^{2}$ Communication Study Program, Faculty of Social and Political Sciences, University of Medan Area, \\ Indonesia \\ Email: agungsuharyanto@staff.uma.ac.id
}

\begin{abstract}
:
Denai Kuala Village, a coastal village, is a destination for developing photo tourism potential by utilizing natural conditions that are still natural, located in Pantai Labu District, Deli Serdang. Geographical conditions that are still natural, can still be developed as a tourist destination, although demographically it is very possible urbanization. This becomes necessary to get its own attention, because of this condition, one of the solutions is to provide science and technology to the community in order to develop the natural, cultural, and Human Resources potential that is available to increase people's income. If the welfare of the community increases, it will automatically reduce the level of urbanization. In fact, if the growth is significant enough, urban people will flock back to the village and advance their homeland. Based on the results of discussions with the Medan Area University PKM implementation team with the Indonesian Women's Union (SPI) as partners, the problem resolution will be done based on priority scale. Concretely the solution to the problem is: 1) Mapping the tourist area by choosing interesting photo spots for photography; 2) Conducting Training and Website Creation of Denai Kuala Village regarding interesting photo spots for photography and utilizing social media for promotion tools on the internet. From the beach site, grass fields, fish drying fields, rivers, ships and bridges, (landscape), mangrove forests and pine forests, has its own uniqueness if processed into its own tourism potential. Some elements of nature $d u$ top, can be made one model for specific spots in areas that are in accordance with the aesthetic of photography. These angles are taken with a photo camera. These results are then disseminated to residents, especially and training to residents, especially female kaun, to recognize site specific photography in Denai Kuala Village, as a tourism potential. Photo documentation obtained, then selected into materials to be marketed for solutions to problems in the field of marketing. These materials are made on the website to utilize social media for promotion tools on blogspot.
\end{abstract}

Keywords:

Photography; tourism potentia; denai Kuala

\section{Introduction}

Tourism Destinations are different geographical areas or regions within one or more administrative regions within which there are elements of: tourist attractions, tourism facilities, accessibility, communities and tourists that are interrelated and complementary to the realization of tourism activities. An attraction that is not or has not yet been developed is a potential resource and cannot be called a tourist attraction, until there is a certain type of development. Tourism objects and attractions are the basis for tourism. Without an attraction in a certain area or place, tourism is difficult to develop. According to the World Tourism Organization (1995), in Arjana (2015), tourism is the activity of people who travel to and live in a place outside the environment usually for a period of less than one year in a row to take advantage of free time, business affairs and other purposes. 
Various understanding grids of tourism destinations, as well as being adapted from many understanding constraints that have been given by experts, basically contain the same goal that the framework of developing tourist destinations must at least include the following main components (Sunaryo, 2013).

a. Objects and attractions which include: attraction based primarily on natural, cultural, or artificial wealth.

b. Accessibility, which includes transportation system support which includes: transportation routes or routes, terminal facilities, airports, ports and other modes of transportation.

c. Amenitas, which includes supporting and supporting tourism facilities which include: accommodation, restaurants, souvenir shops, money exchange facilities, travel agents, tourist information centers, and other leisure facilities.

d. Supporting facilities, namely the availability of supporting facilities used by tourists such as banks, telecommunications, post, health services, and so on.

e. Institutional, which is related to the existence and role of each element in supporting the implementation of tourism activities including the local community as the host.

Serdang Bedagai Regency is one of the regions in North Sumatra Province rich in coastal tourism potential, cultural tourism, nature tourism, education tourism and other tourism potentials to be developed, considering Serdang Regency Law No. 9 of 1990 concerning: Serdang Bedagai tourism has a range of regions beach to the plateau. These tourism objects have been developed, are developing and have the potential to be developed.

One of the most potential and potential natural attractions to be developed in this district is the type of beach tourism. Geographically, what is meant by the coast is an area that belongs to the mainland to the limit of the end of the influence of sea waters and water to the extent of the area that is still affected by the land (Fandeli, 2002). The beach is a natural tourist attraction that is very crowded by both local and foreign visitors.

In Serdang Bedagai Regency there are three beaches that are quite famous, namely Cermin Beach, Labu Beach, Klang Beach and Berhala Island (still not managed properly). Of the three attractions of this beach, seen from the development and the potential that exists, can be seen the number of visitors crowded, even though only local visitors. On Sundays and certain holidays, the crowds of people and attractions are not clearly visible on this beach. That is to say that existing tourist attractions are identified or could have been developed into quality tourist attractions and have good accessibility as said by Hadinoto (1996). The object that is in Berhala Island and 3 islands around it is not so developed, because it is a protected area and as a defense area for the Navy.

Denai Kuala Village, a destination for developing photo tourism by utilizing natural conditions, is located in Labu Beach District, Deli Serdang. is a coastal village. Labu Beach District is geographically close enough to the capital of Deli Serdang Regency, Lubuk Pakam. While from Lubuk Pakam to Medan City, it is only $23 \mathrm{~km}$ away. From the demographic side, Pantai Labu Subdistrict is the second highest pre-prosperous population in Deli Serdang Regency. Based on data from the 2014 Deli Serdang Central Statistics Agency, in 2013 there were 2,293 underprivileged families in Pantai Labu District. 
Geographical conditions that are still natural, can still be developed as a tourist destination, although demographically it is very possible urbanization. The impact of urbanization is one of the abandonment of productive workers who migrate to the city, so that it becomes an underdeveloped area and results in a low community economy. This becomes necessary to get its own attention, because of this condition, one of the solutions is to provide science and technology to the community in order to develop the natural, cultural, and Human Resources potential that is available to increase people's income. If the welfare of the community increases, it will automatically reduce the level of urbanization. In fact, if the growth is significant enough, urban people will flock back to the village and advance their homeland.

In terms of human resources, coastal communities generally do not involve women as the main breadwinner in the family. This is because traditional fisheries sector is still very dependent on physical strength. Seeing this, women's groups are very potential to develop other economic sectors outside of fisheries. Women's groups can be trained to manage the tourism sector, ranging from lodging facilities, culinary, to souvenirs. For this reason, the Science and Technology Program for the Community is directed to develop this potential.

From a general description of the condition of the community in Denai Kuala Village, SPI (Indonesian Women's Union) Hapsari Deli Serdang, found that the income per household of the villagers was only around $\mathrm{Rp} 1.3$ million. The main breadwinners are men (fathers), the majority of whom work as fishermen and a small number of farmers do farming. While the women's group, generally only as a housewife. Some others, to supplement their income, work as salted fish factory workers.

In assisting SPI (Indonesian Women's Union) Hapsari Denai Kuala Village, Deli Serdang Regency, women's groups in this case began to activate the economy with several activities such as making cassava chips and processed sea fish (into anchovy or salted fish). Unfortunately, this activity is seasonal. Only done when there are events that will be held both at the village level and at the district level. Outside of these moments, the activity stops. Thus, the expertise and existing raw materials are not utilized to the full. This is because there are no prospective customers who come to their area so it is not possible to open a shop or shop that sells processed residents' hands. As for online sales, people do not understand this system.

Based on the results of discussions with the Medan Area University PKM implementation team, the problem solving will be based on priority scale. Concretely, the solution to the problem will be: 1) Mapping the tourist area by choosing interesting photo spots for photography; 2) Conducting Training and Website Creation of Denai Kuala Village regarding interesting photo spots for photography and utilizing social media for promotion tools on the internet.

Steps taken in the mapping of tourist areas is to pay attention to existing locations, namely from the beach, grasslands and fish drying lands (landscape), mangrove forests and pine forests. From some of these natural elements, a model will be made to spot specific areas that are in accordance with the aesthetic of self-photographs. After making observations, the spots were taken with a photo camera and model documentation. In the mapping of this tourist area, it is also very good to approach the residents, especially and training the residents, especially female kaun, to recognize site specific photography in Denai Kuala Village, as a tourism potential. 
Photo documentation obtained, then selected into materials to be marketed for solutions to problems in the field of marketing. These materials are made on the website to utilize social media for promotion tools on blogspot. Aspect mapping the potential of tourist areas for photo spots for tourists who come. HR that meets qualified hospitality criteria to facilitate the needs of tourists. Moreover, with the concept of a tourist village, where visitors mingle with the village community (live in), stay, eat, and drink at the community's home.

Management aspects, the resulting outcome is the community is able to utilize information and communication technology (especially internet-based) to carry out promotional and marketing activities. Partners will have accounts on social media and websites that promote and market their tourist villages.

\section{Research Method}

Based on the results of discussions with the Medan Area University PKM implementation team, the problem solving will be based on priority scale. Concretely, the solution to the problem will be: 1) Mapping the tourist area by choosing interesting photo spots for photography; 2) Conducting Training and Website Creation of Denai Kuala Village regarding interesting photo spots for photography and utilizing social media for promotion tools on the internet.

Steps taken in the mapping of tourist areas is to pay attention to existing locations, namely from the beach, grasslands and fish drying lands (landscape), mangrove forests and pine forests. From some of these natural elements, a model will be made to spot specific areas that are in accordance with the aesthetic of self-photographs. After making observations, the spots were taken with photo camera and model documentation. In the mapping of this tourist area, it is also very good to approach the residents, especially and training the residents, especially female kaun, to recognize site specific photography in Denai Kuala Village, as a tourism potential.

Photo documentation obtained, then selected into materials to be marketed for solutions to problems in the field of marketing. These materials are made on the website to utilize social media for promotion tools on BlogSpot.

To be able to produce the expected output, the way to carry out these activities is by involving SPI SPI (Indonesian Women's Union) Hapsari Deli Serdang Denai Kuala Village as a companion who already knows the community of Denai Kuala Village. In addition, to ensure that in each activity the maximum results, experts in the fields in question will be invited to help in various mapping and training activities.

Higher education can connect various elements of society, such as tourism activists. Entrepreneurs and marketing experts and Communication Information Technology experts. Tourism activists have the expertise to assist and manage community-based tourism. Experts in the field of entrepreneurs to market tourism products and ICT experts who support the public to utilize technology to market their products and media that focuses on the tourism segment. These various elements can be utilized to train and support coastal village communities, especially women's groups to create potential tourism villages as a channel to improve their economy. 


\section{Discussion}

\subsection{Spot Site Documentation Photography Specific Photography}

As said by Zainudin (2012: 111) Natural scenery becomes an interesting object to be immortalized. The atmosphere of the mountains, the expanse of fields / rice fields, river currents, and waterfalls can be the center of attention in a photo that has an appeal. Understanding of nature in some dictionaries, among others, thus: Nature according to the Big Indonesian Dictionary Edition 4 (2008 24) "Everything in the heavens and on earth" (Like the earth, stars, strength) around".

Meanwhile, according to the Oxford Advanced Learner's Dictionary (2000: 884) "all the plants, animals, and things that exist in the universe that are not made by people". which means: "all plants, animals and things in the universe that are not made by humans". Nature in the world of photography refers to shooting activities carried out in the field and is closely related to natural elements such as wild life, plants and natural scenery.

According to Mardiyatmo (2006: 66), photos of natural landscapes are landscapes consisting of several elements of sky, land and water. All of these are fused as subjects. Landscape photography According to Abdi, (2011: 19) is: "Photograph of a view of an area. Landscape photography has always been a part of outdoor photography that presents views of the beach, sea, cliffs, rivers, lakes, mountains, forests, and waterfalls.

The main priority of landscape photography is scenery, by sharpening the view and exploring beauty. The presence of humans and animals can be excluded or not included but if there is it only as a comparison scale. The most important thing in capturing landscapes is place, time and object."

Meanwhile according to. Sukarya (2011: 78) is: "Landscape photos have captivated photography lovers since the beginning of their birth. As one of the most popular fields of photography, landscape photography encompasses a very broad and specific subject area. From real natural beauty to abstract, from simple to complex. There is no field of photography that is able to unite a variety of subjects that are so broad and sometimes seem contradictory into one harmonious blend of images."

Landscape photography consists of visible features of land area, including physical elements of the landscape such as mountains, hills, water bodies such as rivers, lakes, ponds and seas, living elements of land cover, including native vegetation, including various forms of land use, and mortal elements such as lighting and weather conditions. To get a good landscape photo, many factors influence it, such as the camera and lens used, the aperture that will affect the level of depth of field or the overall sharpness level of an image. The more thorough and sharp the photo the better.

The development of tourism will not be separated from physical and non-physical elements. The physical and non-physical elements will be taken into consideration in matters relating to the carrying capacity of objects and consideration of the impacts that result from tourism development. The development of tourism in a tourist destination must be based on planning, development, and direction of management (Suarta, 1994; Suharyanto, 2017; Suharyanto, et.al, 2019). The systematic development of tourism and the direction of management itself greatly require government attention, as reflected in the formation or recognition of the National Tourism Organization. Local governments have 
Britain International of Humanties and Social Sciences (BIoHS) Journal

ISSN: 2685-3868(Online), 2685-1989(Print)

Vol. 2, No. 1, February 2020, Page: 100-108

an important role in tourism development, including formulating policies in tourism development and acting as a means of monitoring tourism activities so that they are expected to be able to maximize the potential of tourism destinations

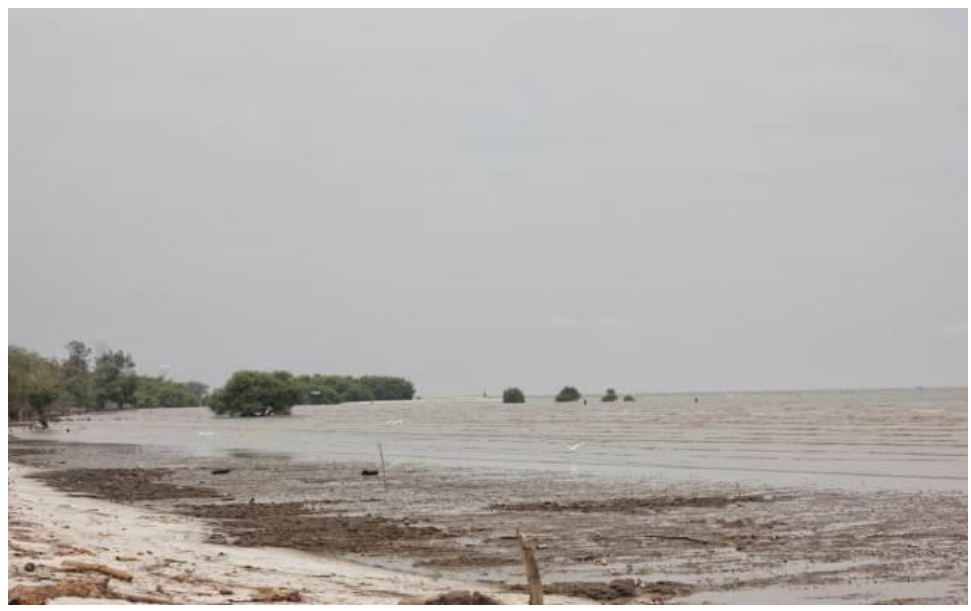

Figure 1. Beach Site

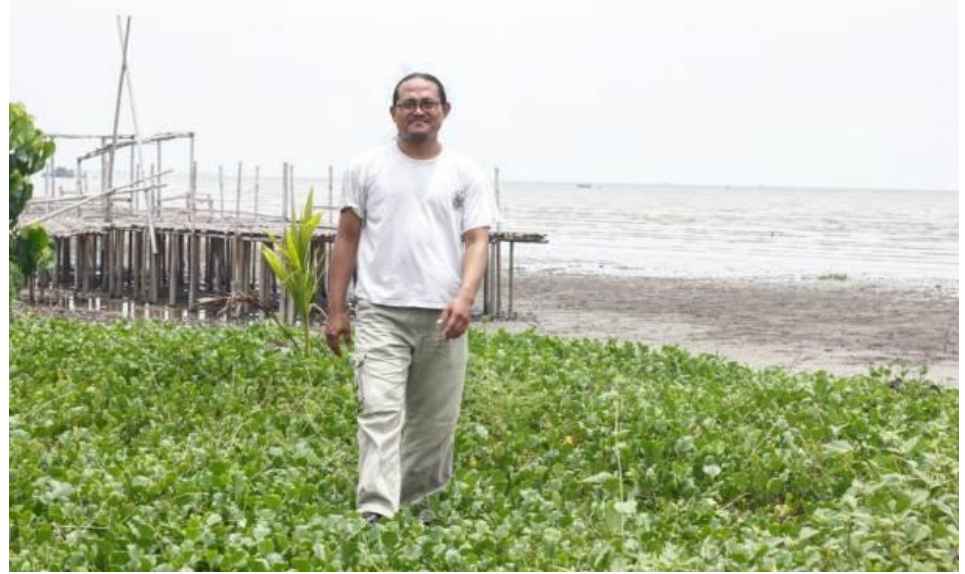

Figure 2. Grassland Site

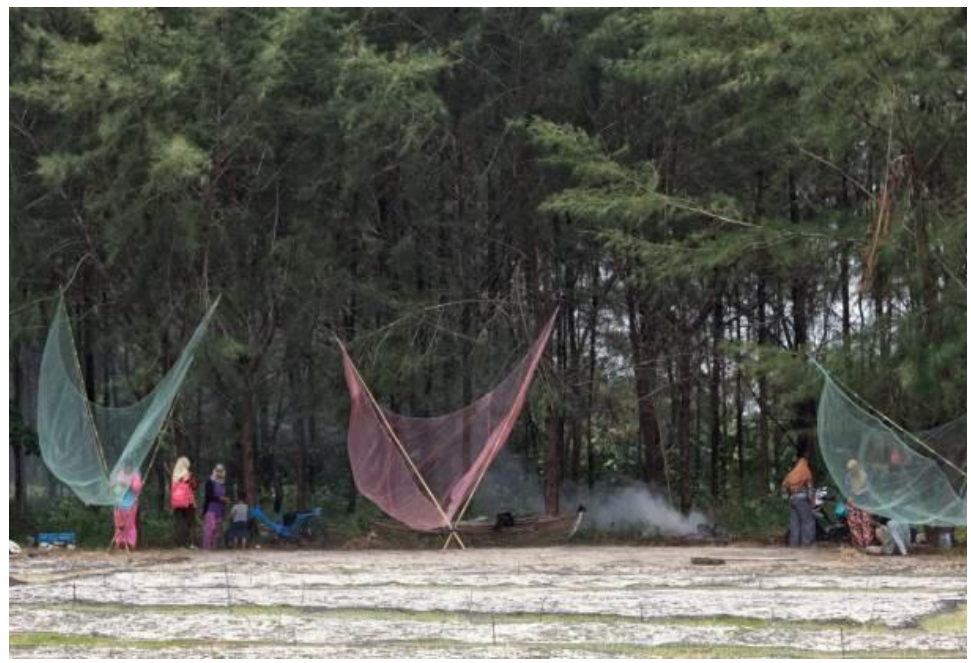

Figure 3. Fish Drying Field Site 
Britain International of Humanties and Social Sciences (BIoHS) Journal ISSN: 2685-3868(Online), 2685-1989(Print)

Vol. 2, No. 1, February 2020, Page: 100-108

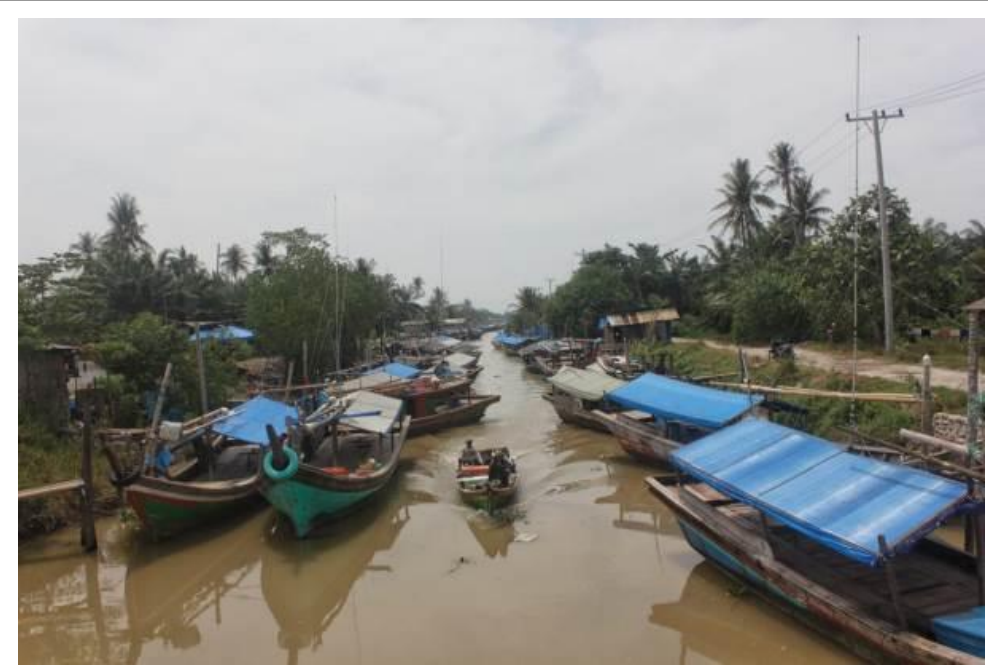

Figure 4. River and Bridge Site
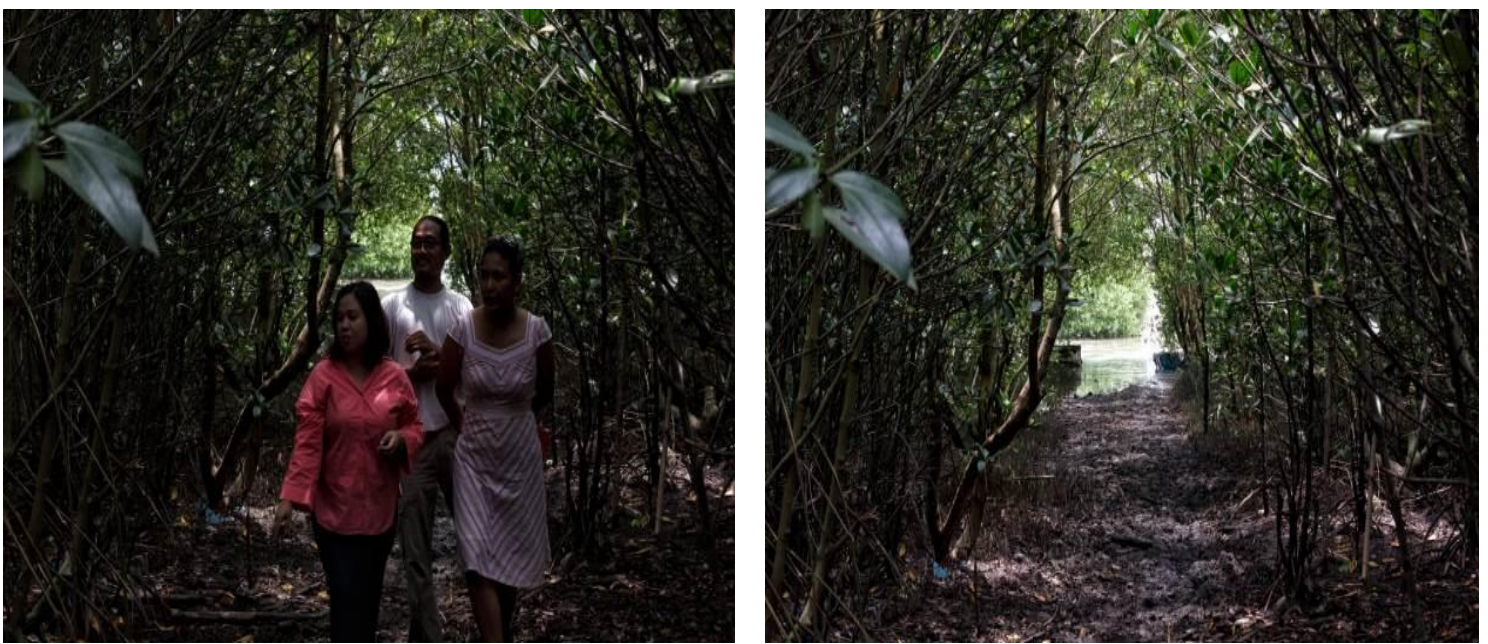

Figure 5. Mangrove Forest Site

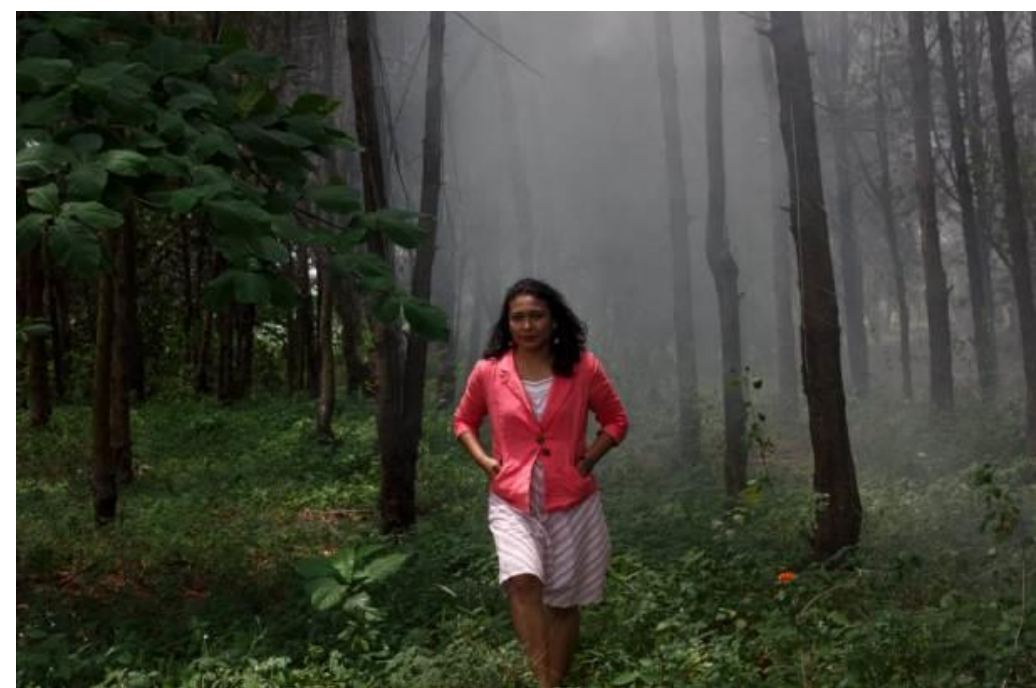

Figure 6. Fir Forest Site 


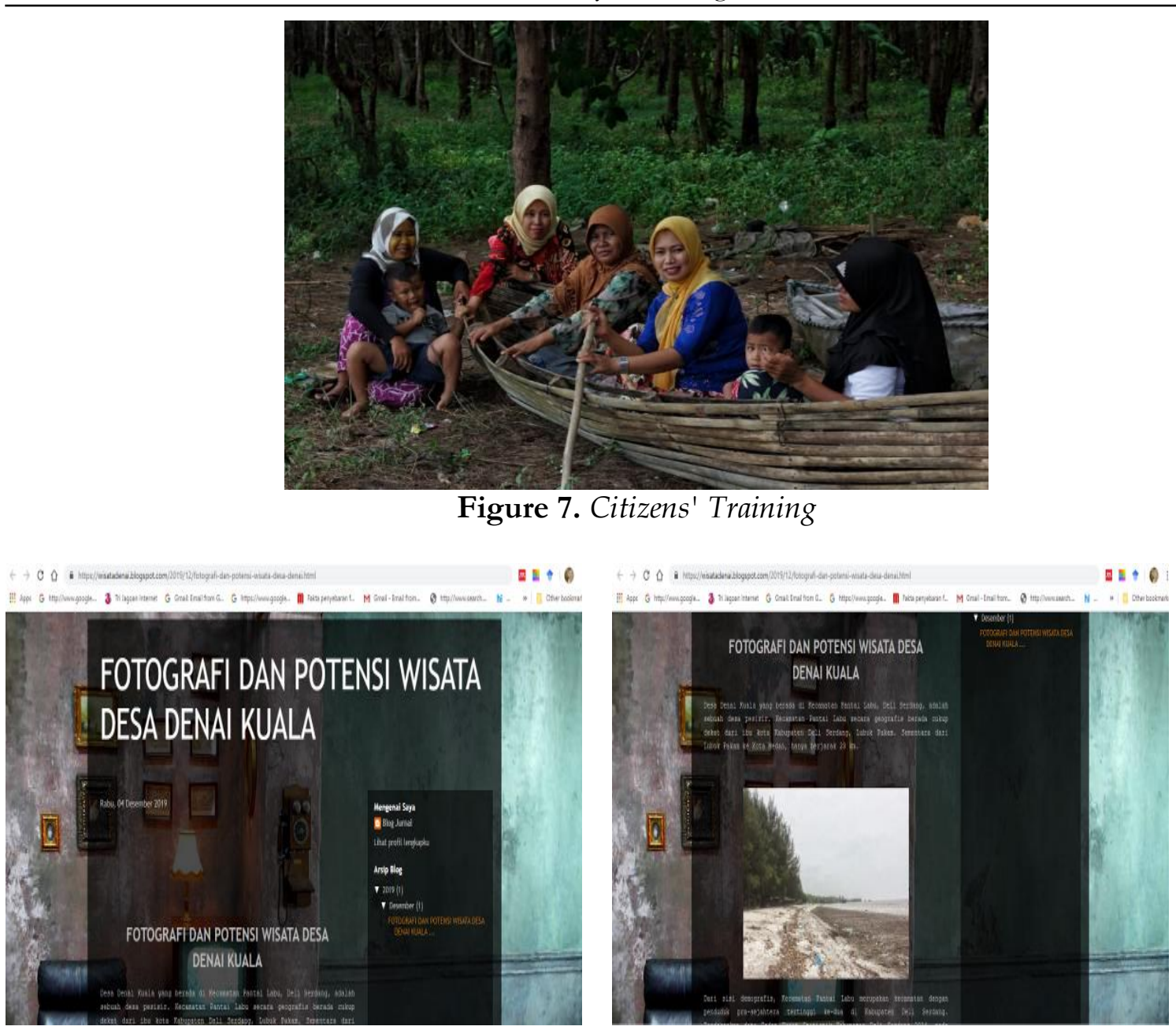

Figure 8. Website and Social Media Utilization for Promotion Tools

Site-specific photography as a tourism potential in Denai Kuala Village: https://wisatadenai.blogspot.com/2019/12/photography-and-potency-touring-desadenai.html

\section{Conclusion}

One of the most potential and potential natural attractions to be developed in this district is the type of beach tourism. Geographically, what is meant by the coast is an area that belongs to the mainland to the limit of the end of the influence of sea waters and water to the extent of the area that is still affected by the land (Fandeli, 2002). The beach is a natural tourist attraction that is very crowded by both local and foreign visitors.

The beauty of the beach as a very interesting tourist attraction if there are islands or sea mountains on the location, there are corals, there are marine life, the view can be seen from above, the waves are high between 1-2 m. In the location of the tourism object of Serdang Bedagai Regency, the condition was not found, only sand was found on the seashore, so the potential of the object in terms of this aspect makes it potential. For that we need to develop attractions for photography.

From the beach site, grass fields, fish drying fields, rivers, ships and bridges, (landscape), mangrove forests and pine forests, has its own uniqueness if processed into its 
own tourism potential. Some elements of nature du top, can be made one model for specific spots in areas that are in accordance with the aesthetic of photography. These angles are taken with a photo camera. These results are then disseminated to residents, especially and training to residents, especially female, to recognize site specific photography in Denai Kuala Village, as a tourism potential. Photo documentation obtained, then selected into materials to be marketed for solutions to problems in the field of marketing. These materials are made on the website to utilize social media for promotion tools on blogspot.

\section{References}

Anonim, (1990). Undang-Undang Nomor 9 Tahun 1990 tentang kepariwisataan, Dinas Pariwisata.

Anonim, (2013). Profil Investasi Pariwisata Kabupaten Serdang Bedagai: Kantor pariwisata Kabupaten Serdang Bedagai.

Arjana, I Gusti Bagus. (2015). “Geografi Pariwisata dan Ekonomi Kreatif”. Jakarta: PT RajaGrafindo Persada.

Badan Perencanaan Pembangunan Daerah (BAPPEDA) Kabupaten Serdang Bedagai, Sumatera Utara: Badan Pusat Statistik Kabupaten Serdang Bedagai.

Badan Perencanaan Pengembangan Daerah (BAPPEDA) Kabupaten Serdang Bedagai (2010), 20132033, Penyusunan Tata Ruang Wilayah Serdang Bedagai. Sumatera Utara: Pemerintah kabupaten Serdang Bedagai.

Departemen Pariwisata Pos dan Telekomunikasi, (1990). Undang-Undang Republik Indonesia No 9 7'ahhun 1990 tentang Kepariwisataan. Jakarta: Departemen Pariwisata Pos dan Telekomunikasi.

Fandeli, C. (2000). Perencanaan Kepariwisataan Alam, Fakultas Kehutanan Universitas Gajah Mada, Yogyakarta.

Hadinoto, K, (1996), Perencanaan Pengembangan Destinasi Pariwisata. Universitas Indonesia Press, Edisi Revisi: Jakarta.

Mardiyatmo. (2006). Diklat Mata Kuliah Fotografi Ii. Yogyakarta: UNY Press. Abdi, Yuyung. 2012. Photography from My Eyes. Jakarta: PT. Elex Media Komputindo.

Pemerintah Daerah Tingkat II Serdang Bedagai. (2004). Rencana Umum Tata Ruang. Serdang Bedagai: Bappeda Tingkat II Serdang Bedagai.

Suartha, N, (1994). Pengaruh Pariwisata Terhadap Lingkungan Sosial Ekonomi masyarakat Desa Batubulan Daerah Tingkat II Gianyar. Tesis S-2 Program Pasca Sarjana Universitas Gajah Mada.

Suharyanto, Agung. (2017). Meningkatkan Berpikir Kritis Mahasiswa Pada Objek Pariwisata Dengan Menggunakan Pendekatan Langsung Ke Subjek Penelitian, Prosiding Seminar Nasional Tahunan Fakultas Ilmu Sosial Universitas Negeri Medan Tahun 2017: 308-311.

Suharyanto, Agung., Febryani, Ayu., Wiflihani \& Batubara, Beby Masitho (2019), Village Government Policy on Tourism Management in Situngkir Village, Proceedings of the 2nd International Conference on Social Sciences and Interdisciplinary Studies (formerly ICCSSIS), ICCSIS 2019, 24-25 October 2019, Medan, North Sumatera, Indonesia

Sunaryo, Bambang. (2013). Kebijakan Pembangunan Destinasi Pariwisata Konsep dan Aplikasinya di Indonesia. Yogyakarta: Gava Media

Zainudin, Zaslina. (2012). Kreasi Maksimal Dengan Kamera Digital Minimal. Jakarta: PT Elex Media Komputindo. 